\title{
Identification of microalgae from waste stabilization ponds and evaluation of electroflotation by alternate current for simultaneous biomass separation and cell disruption
}

\author{
Identificação de microalgas de lagoas de estabilização \\ e avaliação do método de eletroflotação por corrente \\ alternada para separação e ruptura celular simultâneas
}

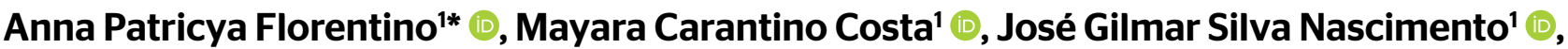

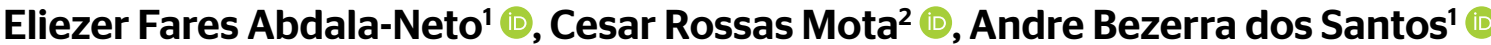

\begin{abstract}
This work aimed to investigate algal diversity at the genus level in stabilization pond systems treating domestic wastewater and to evaluate the feasibility of an electroflotation by alternate current (EFAC) system for simultaneous microalgae separation and cell disruption. Evaluation of algal diversity showed that the genera Euglena and Chlorella were present in relatively high frequencies in five of the six effluents analyzed. The use of EFAC on an effluent that presented bloom of Chlorella achieved turbidity and chlorophyll-a removal efficiencies higher than 70 and 90\%, respectively, after 70 minutes of operation. Total lipid yield for the Chlorella-rich biomass was $21.4 \pm 2.02 \%$. Such high biomass lipid content demonstrates the potential for obtaining lipid-based biofuels from wastes. The current paper describes the first attempt, with promising results, at using electroflotation by alternate current for low cost, simultaneous microalgae harvesting and disruption
\end{abstract}

Keywords: microalgae biomass; waste stabilization pond; lipid; electroflotation by alternate current.

\section{RESUMO}

Este trabalho objetivou investigar a diversidade algal no que se refere a gênero em sistemas de lagoas de estabilização tratando esgoto doméstico, bem como analisar a viabilidade de um sistema de eletroflotação por corrente alternada para obter simultaneamente separação e ruptura celular. A avaliação de diversidade algal mostrou que os gêneros Euglena e Chlorella estiveram presentes com relativamente elevada frequência em cinco dos seis efluentes analisados. A aplicação de eletroflotação por corrente alternada em um efluente que apresentou elevada predominância de Chlorella alcançou eficiências de remoção de turbidez e clorofila-a maiores que 70 e 90\%, respectivamente, depois de 70 minutos de operação. O rendimento de lipídios totais para a biomassa rica em Chlorella foi de 21,4 $\pm 2,02 \%$. Esse elevado teor lipídico demonstra potencial para obtenção de biodiesel de lipídios de efluentes. O presente artigo descreve uma primeira tentativa, com resultados promissores, da utilização de eletroflotação por corrente alternada para separação e ruptura celular simultânea com baixo custo.

Palavras-chave: biomassa microalgal; lagoas de estabilização; lipídios; eletroflotação por corrente alternada.

\section{INTRODUCTION}

The use of non-renewable resources of fuels, agricultural nutrients and metals offers long-term sustainability issues for the current societal production system (LOVINS, 2008). The search for sustainable bio-based resources has been driving the production cycles in the world, in which raw material can be generated from technical and biological waste. Wastewater treatment is a key platform for the technological development focused on the change of production system (VAN LOOSDRECHT \& BRDJANOVIC, 2014). Wastewater contains between 50 and $100 \%$ of lost waste resources. Therefore, the recovery and reuse of such resources 
have been the target of economists and environment experts (PUYOL et al., 2017).

Among the technologies contributing to the challenge of resource recovery from wastewater, biological ones, such as heterotrophic, chemotrophic, phototrophic, and photosynthetic bacteria, microalgae, and terrestrial plants, have been reaching highly efficient recovery of valuable resources from dilute streams (PUYOL et al., 2017; CHEN et al., 2017; RAZZAK et al., 2017).

Waste stabilization ponds are lentic environments built to treat wastewater by removing organic matter through biological processes (PEARSON, 2008). Microalgae play an important role in these ecosystems, consuming carbon dioxide and nutrients and producing oxygen that is used by bacteria to oxidize organic matter. Moreover, they can influence physicochemical conditions by modifying the color, turbidity, oxygenation, alkalinity and other properties of the ponds (RAWAT et al., 2011; BAHR et al., 2011; MUÑOZ \& GUIEYSSE, 2006).

Although highly important during treatment, microalgae can have a negative impact on the quality of receiving water bodies due to their high content of organic matter, nitrogen and phosphorus, which can be used as substrate for bacterial growth (RAWAT et al., 2011; MULBRY et al., 2008; DE-BASHAN \& BASHAN, 2010). Unfortunately, most stabilization pond systems do not have a polishing step for microalgae removal before final discharge. If harvested during treatment in stabilization ponds, algal biomass can have commercial value due to its potentially high content of lipids, which could be used for the production of biofuels (RAWAT et al., 2011; DERNER et al., 2006). The lipid content of microalgae can vary considerably among species, ranging from 2 to $77 \%$ of their dry weight (CHISTI, 2007; MATA et al., 2010).

Despite the importance and great diversity of algae in waste stabilization ponds, there are few references in the current scientific literature to taxonomic surveys, and studies of the algal community structure of these environments (PHAM et al., 2014; PASTICH et al., 2016). Algal diversity in these systems is greatly influenced by the design parameters, environmental conditions such as temperature, solar radiation, domestic wastewater quality, etc., as well as operation conditions (PEARSON, 2008; MARA \& HORAN, 2003). Thus, the diversity obtained in each system can influence the oil content that can be extracted from the biomass.

Biomass separation from water during production of biodiesel from algae may involve one or more steps and makes up to $20-30 \%$ of total production costs (RAWAT et al., 2011). The main reasons for high process costs are the small size of microalgae and their growth in very dilute cultures (biomass concentration lower than $1 \mathrm{~g} \mathrm{~L}^{-1}$ ) and similar density to water (BARROS et al., 2015; SHUBA \& KIFLE, 2018). There is high demand for the development of appropriate and economically viable technologies for microalgal harvesting, which involves the combination of existing technologies or the development of brand new ones (MATA et al., 2010; GRIMA et al., 2003; BRENNAN \& OWENDE, 2010; BARROS et al., 2015; RASLAVIČIUS et al., 2018; SHUBA \& KIFLE, 2018). Current microalgal harvesting processes involve mechanical, chemical, biological and, to a lesser extent, electrical based methods.

Electrochemical processes generally generate hydroxyl radicals on the electrode (CHAPLIN, 2014; SIRÉS et al., 2014), and those radicals are responsible for the complete oxidation of the organic matter and its conversion to $\mathrm{CO}_{2}$ and $\mathrm{H}_{2} \mathrm{O}$. In this way, the undesirable compounds cannot be transferred between the phases of the process (PARSA et al., 2009). Therefore, the electroflotation process works as a solid/liquid separator based on the suspension of gas particles (hydrogen and oxygen) generated on the surface of the electrodes (ARAYA-FARIAS et al., 2008). In conventional flotation processes, the diameter of the gas bubbles produced varies from 600 to $1,000 \mu \mathrm{m}$. Due to the large size of the diameters, the gas bubbles cannot efficiently provide the flotation of particles with diameter smaller than $20 \mu \mathrm{m}$. However, bubbles generated by electroflotation have a diameter of 15 to $80 \mu \mathrm{m}$, which works efficiently in the flotation of small particles (SARKAR et al., 2011). Although the motion of an ion in solution is always uncertain, the presence of an electric field inserts a guided movement component and the ions migrate through the solution. In the frequency range applied, a resonance is obtained with the natural frequency of the water molecule, which breaks the atoms connections.

This work aimed to investigate algal diversity at the genus level in stabilization ponds treating domestic wastewater and to evaluate the feasibility of electroflotation by alternate current (EFAC) for simultaneous separation and disruption of microalgal cells.

\section{MATERIALS AND METHODS}

\section{Phytoplankton diversity}

\section{Sampling}

Six waste stabilization ponds were selected for the evaluation of their phytoplankton diversity (Table 1). These systems were located in Fortaleza, Ceará, Brazil. Samples were collected near the outlet on the surface of the last pond at each system. For physicochemical analyses, samples were collected in $20 \mathrm{~L}$ plastic containers.

Samples for microscopic identification were collected using a plankton nylon net with $20 \mu \mathrm{m}$-pores (Sulpesca, Paraná, Brazil) and stored in sterile $200 \mathrm{~mL}$ glass containers. Although some microalgae have smaller sizes than the openings used, the filtered volume enables the collection of many species at random, allowing the study of phytoplankton diversity. 


\section{Physicochemical parameters}

Samples were analyzed for $\mathrm{pH}$, dissolved oxygen (DO), temperature, turbidity, chlorophyll-a, nitrite, nitrate, ammonia, total phosphorus, biochemical oxygen demand (BOD), chemical oxygen demand (COD) and alkalinity. All physicochemical parameters were determined according to Standard Methods for the Examination of Water and Wastewater (APHA; AWWA; WEF, 2008).

\section{Microscopic identification}

Samples were placed in a sterile glass container and fixed with Transeau solution (6 parts of water, 3 parts of 95\% ethanol and 1 part of formaldehyde) in a 1:1 ratio (effluent:Transeau) (SILVA et al., 2014). Transeau solution was used only to preserve the morphology of microalgal specimens, and these samples were used exclusively in the microalgae identification assays. Slides were prepared with $20 \mu \mathrm{L}$ of the prepared solution covered with a glass slide.

Identification of the dominant genus was carried out in five slides and each slide was checked twice - with direct light in a trinocular optical microscope (L-1000T, Bioval, São Paulo, Brazil), using a 40X objective and taxonomic identification guides (BELLINGER \& SIGEE, 2010; HUYNH \& SEREDIAK, 2006).

\section{Simultaneous microalgae separation and cell disruption}

\section{Reactor design}

The EFAC system used in this study to achieve simultaneous separation and cell disruption is shown in Figure 1.

The EFAC reactor was built in polyvinyl chloride, with a working volume of approximately $45 \mathrm{~L}, 60 \mathrm{~cm}$ high and diameter of $40 \mathrm{~cm}$. In its lower part, there is a polyvinyl chloride drainage port $(1.3 \mathrm{~cm}$ of diameter) used for cleaning and/or sampling. The central cylinder, also made in polyvinyl chloride, had $20 \mathrm{~cm}$ diameter and the same height of the outside cylinder. At its bottom, a second polyvinyl chloride drainage port was installed with $1.3 \mathrm{~cm}$ diameter. The cathode and anode used were made of five 316-stainless steel bars, resistant to oxidative action, measuring $15 \times 5 \mathrm{~cm}$, thickness $0.2 \mathrm{~mm}$, and spaced at $5 \mathrm{~mm}$ for each electrode. A direct current/alternating current converter (HY 125 Hobby, Hayama, Paraná, Brazil) was used to apply a voltage of $12 \mathrm{~V}$ and a maximum current of $5 \mathrm{~A}$, generating a frequency band from 0 to $1.5 \mathrm{KHz}$, corresponding to a range of $0-4,000 \mathrm{~cm}^{-1}$ wave numbers.

Table 1 - Configurations of the waste stabilization ponds systems selected.

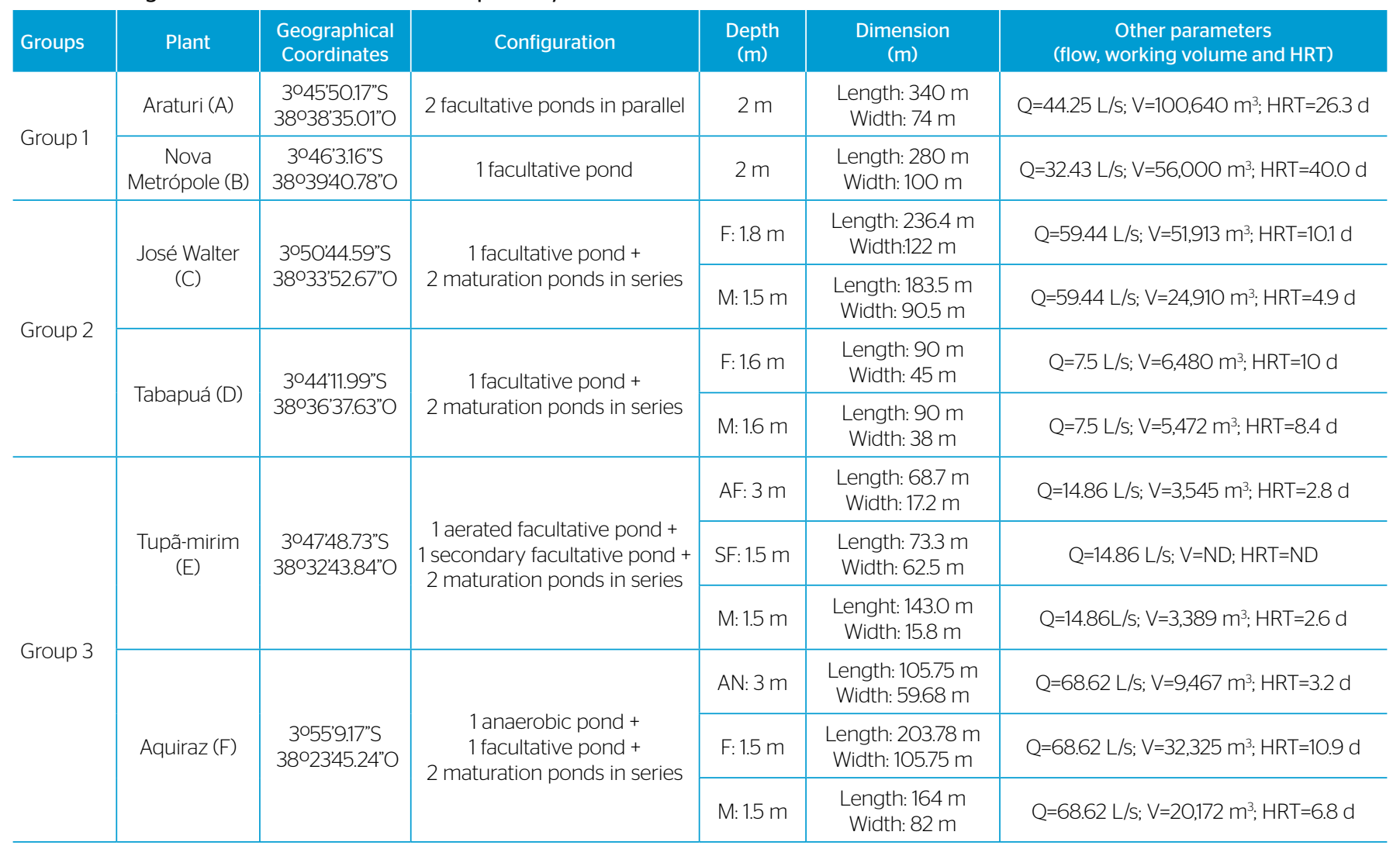

F: facultative pond; M: maturation pond; AF: aerated facultative pond; SF: secondary facultative pond; AN: anaerobic pond; HRT: hydraulic retention time; Q: flow; V: working volume; ND: not determined. 


\section{Dewatering and cell disruption}

Following phytoplankton diversity studies, one of the six systems evaluated was selected for dewatering and cell disruption experiments. Samples were collected directly near the outlet of system B (1 facultative pond - Table 1).

The algal contents of the suspensions were measured before and after harvesting by EFAC in terms of turbidity and chlorophyll-a, after 40, 70, 120 and 140 minutes of batch operation. Floated microalgal cells were collected and lyophilized (L202, Liotop, São Paulo, Brazil) for subsequent lipid extraction.

The efficiency of EFAC for cell disruption was determined by the method described by Bligh and Dyer for lipid extraction (BLIGH \& DYER, 1959). Dried biomass (500 mg) was diluted with $2.5 \mathrm{~mL}$ of methanol, $1.25 \mathrm{~mL}$ of chloroform and $1 \mathrm{~mL}$ of deionized water and then homogenized in a shaker for $20 \mathrm{~min}$, after which $1.25 \mathrm{~mL}$ of chloroform and $1.25 \mathrm{~mL}$ of $1.5 \%$ sodium sulfate was added and the solution was shaken for $2 \mathrm{~min}$ for further homogenization.

The homogenized sample was centrifuged at 1,000 rpm for $2 \mathrm{~min}$ (Excelsa II 206 BL, Fanem, São Paulo, Brazil). The chloroform-methanol phase, which contains the extracted lipids, was separated by filtration using a funnel with mild suction followed by the evaporation of the solvent in an oven at $100^{\circ} \mathrm{C}$ until constant weight was achieved. The mass of the lipid obtained from each sample was determined gravimetrically.

\section{Data analysis}

The efficiency of the EFAC method on cell disruption was determined based on the lipid yield, which was calculated by the ratio of total lipid extracted and the initial weight of microalgae. Statistical analyses of biomass separation results were performed using Microcal Origin 8.6 (OriginLab, Massachusetts, United States).

Simple bivariate correlation analysis was used to evaluate correlation between physicochemical parameters and the number of organisms that occur by genus (bloom) of microalgae detected. A Spearman correlation coefficient of 0.05 was used.

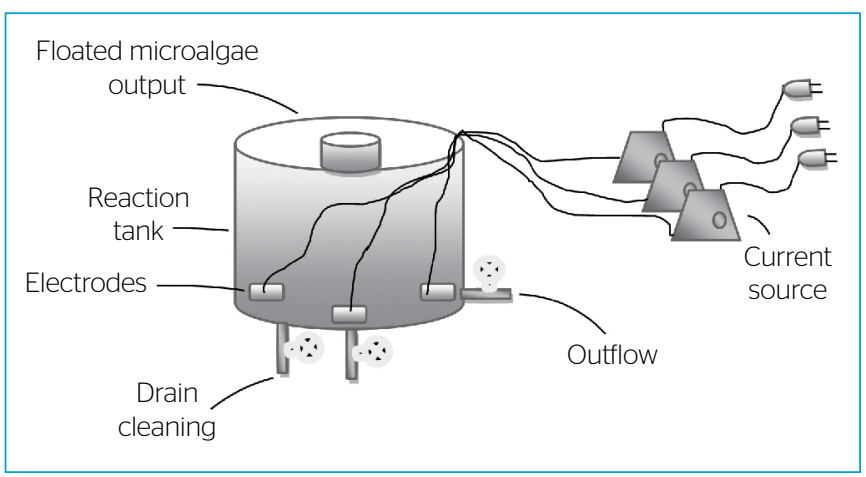

Figure 1 - Schematic diagram of the electroflotation by alternate current (EFAC) reactor used for simultaneous biomass separation and cell disruption.

\section{RESULTS AND DISCUSSION}

\section{Phytoplankton diversity}

A total of 21 phytoplankton genera, distributed in five classes, were identified on samples from the six stabilization ponds evaluated. Five of the genera detected belong to the Cyanophyceae class, six to the Chlorophyceae, four to the Euglenophyceae, five to the Bacillariophyceae and one to the Zygnemaphyceae class (Table 2).

Although the samples were obtained from systems with different configurations (Table 1), phytoplankton diversity did not vary considerably. Samples from facultative ponds presented the same phytoplankton diversity, at the genus level, of other ponds such as maturation or facultative aerated ponds (Tables 1 and 2).

The class Cyanophyceae was the most diverse, presenting, in general, greater number of genera in comparison with other classes, except for system A, in which no genus of that class was identified, neither rare genera of the other classes nor a Euglena bloom were detected (Table 2).

Classes of Bacillariophyceae, Cyanophyceae, Chlorophyceae and Euglenophyceae were well represented in all studied effluents, with blooms of the genera Aphanocapsa, Planktothrix, Chlorella and Euglena (Table 2). These results are corroborated by the data of Patil et al. (1975), suggesting that these organisms are predominant only after the pond stabilization. These results are also in accordance with Palmer (1969), Padisák et al. (2003) and Bellinger \& Sigee (2010), however they analyzed environments with high organic loads. In other reports, Di Bernardo (1995) concluded that cyanobacteria predominate in environmental conditions of low $\mathrm{pH}$ and low nutrients, which may explain, in this study, the blooms verified in systems A and D (Tables 2 and 3). Pham et al. (2014) studied the spatial distribution of the algal community at different levels of BOD and also reported that the distribution was associated with the BOD concentration of the system. On the region of the pond with BOD of $74 \mathrm{mg} \mathrm{L}^{-1}$, the community was dominated by motile algal species such as Euglena and Cryptophytes. When the BOD concentration decreased, the algal community was more evenly distributed and nonmotile species such as Chlorophytas and Chrysophytes were also present.

Genera Euglena, Chlorella and Chlamydomonas are considered the most tolerant to pollution by high organic matter compounds and present great adaptation capacity to climate change (PALMER, 1969). Other genera found by that author in conditions of high organic loads were Scenedesmus, Nitzschia, Navicula, Oscillatoria and Stigeoclonium. Patil et al. (1975) noted in their studies that euglenoid organisms were better adapted to conditions of low organic matter and nutrients concentrations, in contrast to the results obtained by Palmer (1969). In the present study, the genera Euglena and Chlorella were found in relatively high frequencies in five of the six effluents evaluated. The absence of these genera in the waste stabilization ponds system $\mathrm{F}$ can be justified by the blooms of cyanobacteria in the genera Aphanocapsa and 
Planktothrix, which can cause the decrease of microalgae diversity when in high frequency (CHELLAPPA \& COSTA, 2003).

The use of molecular biology techniques to study microalgae in natural and engineered freshwater systems are not yet well established. Very few studies focus on microalgae present in wastewater treatment plants. Ghosh \& Love (2011) evaluated the molecular diversity of algae in the final clarifier or denitrification filter outfall from three wastewater treatment plants with activated sludge-based treatment. The molecular diversity was analyzed using the ribulosebisphosphate carboxylase ( $\mathrm{rbcL}$ ) gene as a phylogenetic marker. The $\mathrm{rbcL}$ gene encodes the large subunit of the $\mathrm{CO}_{2}$ fixing enzyme ribulose-1,5-bisphosphate carboxylase/oxygenase (RuBisCO). Diatoms, green algae, cyanobacteria, Eustigmatophyceae, and unknown heterokonts were identified in this study. The authors reported high level of diversity within the wastewater systems with 19-24 unique rbcL sequences detected at each system. Algae composition also varied between treatment plants.

Eland et al. (2018) used molecular methods and flow cytometry to assess the cyanobacterial and eukaryotic communities longitudinally throughout a domestic wastewater treatment system and one mixed industrial/domestic wastewater system. Chlorella species and Planktothrix cyanobacteria dominated both treatment systems. Flow cytometry showed that the facultative and first maturation pond in the industrial system contained a lower proportion of photosynthetic organisms compared to the domestic system. This was reflected in the species richness data and low dissolved oxygen levels detected in the study.

The effluent from the system $\mathrm{F}$ presented the lowest ratio N:P (5.56 \pm 0.02$)$ (Table 3$)$, justifying the green algae absence on that environment (CUVIN-ARALAR et al., 2004). However, the system B presented bloom of Chlorella genus even for N:P lower than 20:1, contradicting those authors inferences. Organisms of the Bacillariophyceae class did not prevail in these conditions, which also disagrees with the latter investigation (CUVIN-ARALAR et al., 2004).

In order to determine which parameters could be related to the phytoplankton genera predominance in the study, correlations were performed between the number of organisms of each genus and the mean values of each parameter for all effluents. For the correlation analysis, only the six most representative of the 21 identified phytoplankton genera were considered (Tables 2 and 4).

The Spearman correlation coefficient values presented in Table 4 associate the parameters adopted as independent variable to the occurrence frequency of microalgae. It indicates the direction of those associations. The parameters nitrogen, BOD and temperature were the only ones to present a significant relation with the relative occurrence frequency of the genus Oscillatoria, in which $\mathrm{N}$ and BOD interfere negatively with the incidence of that genus $(\mathrm{p}<0.05)$ and temperature interferes positively $(\mathrm{p}<0.01)$. Therefore, increases in concentration of $\mathrm{N}$ and BOD induce the occurrence frequency of that genus, while an

Table 2 - Semi-quantitative distribution of microalgae genera found in the studied stabilization ponds systems.

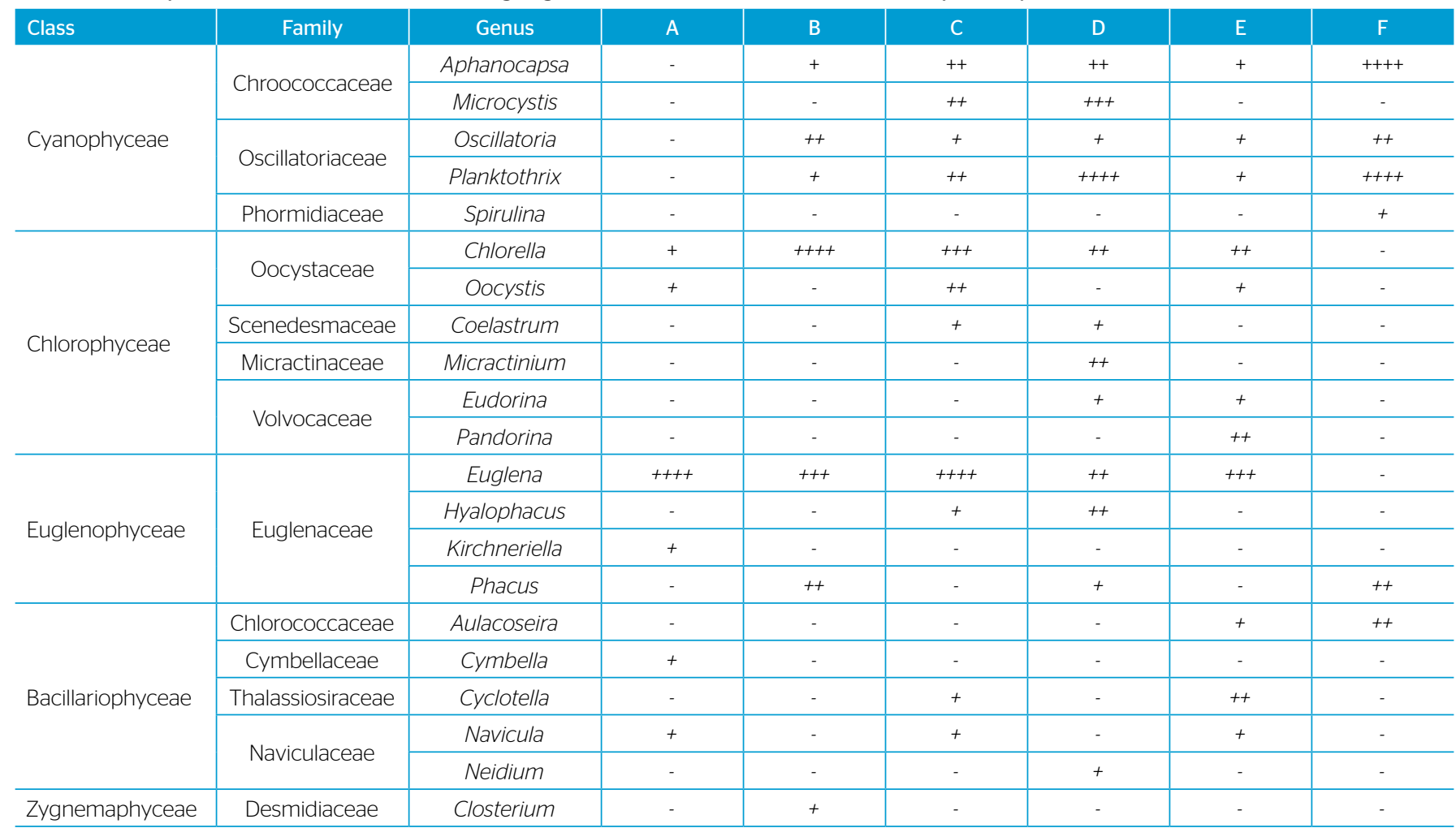


Table 3 - Values of the physic-chemical parameters analyzed in the effluents characterization.

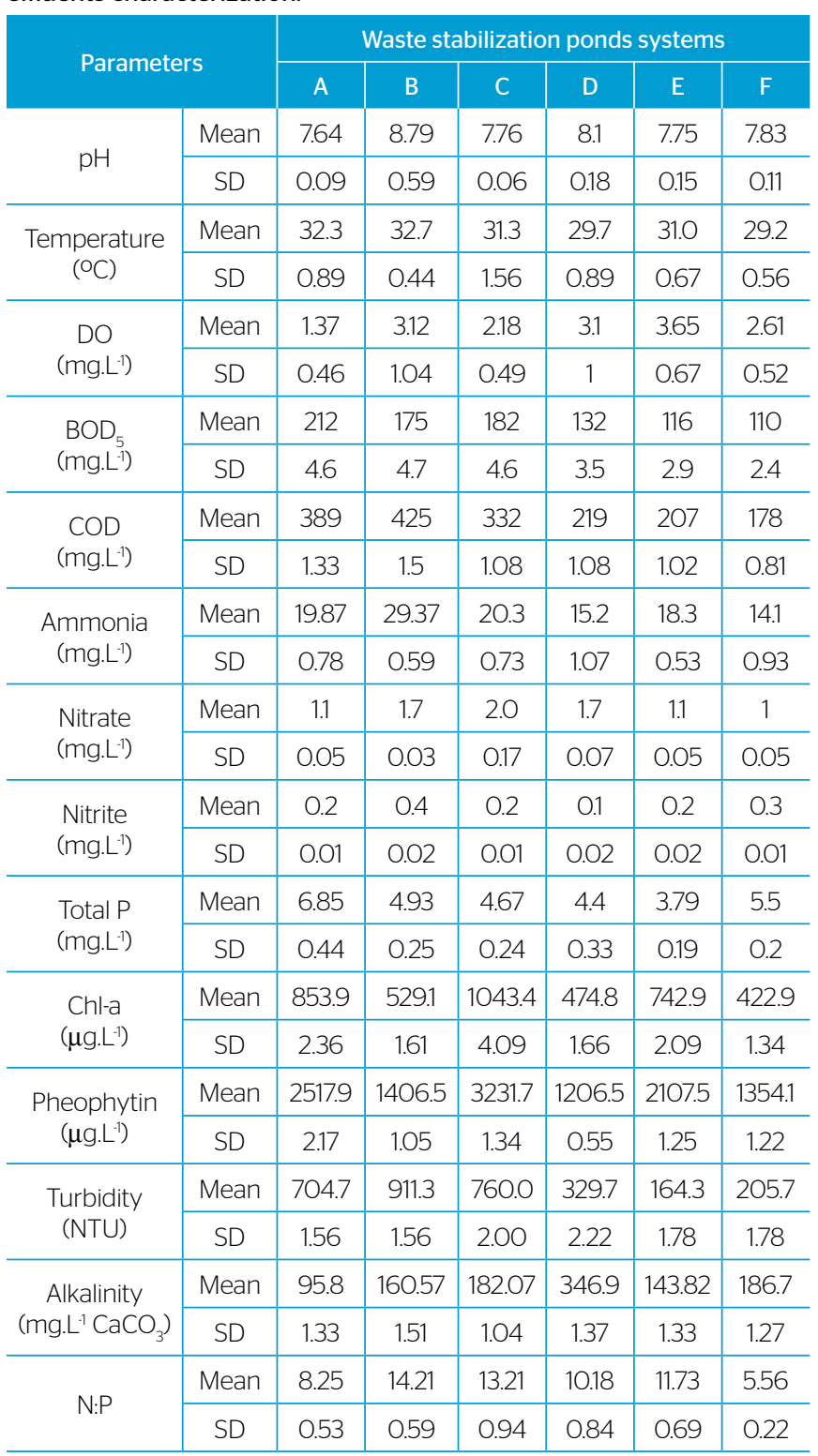

DO: dissolved oxygen; BOD: biochemical oxygen demand; COD: chemical oxygen demand; P: phosphorus; Chl-a: chlorophyll-a. increase in temperate favors its appearance in the waste stabilization pond. For Chlorella, only the total phosphorus was related to the genus, negatively affecting its incidence $(\mathrm{p}<0.05)$, implying that increases in phosphorous concentration lead to a decrease number of cells of Chlorella. For all other organisms, although the Spearman coefficient has varied, there was no significant correlation and therefore any effect of the parameters on the listed genera could not be inferred (Table 4).

\section{Simultaneous microalgae separation and cell disruption}

The use of electroflotation (EFAC) on the effluent that presented bloom of Chlorella revealed high capacity for biomass harvesting. For instance, after 70 minutes of operation, turbidity removal reached values higher than $70 \%$ (Figure 2B). The application of EFAC for longer periods, 120 and 140 minutes, did not show any significant improvement on turbidity removal efficiency ( $\mathrm{p}=0.08$ and $\mathrm{p}=0.07$, respectively).

The same behavior was verified for chlorophyll-a removal, in which after 70 minutes of operation the removal efficiencies were higher than $90 \%$ (Figure 2A), with no statistically significant difference upon comparison with 120 and 140 minutes $(\mathrm{p}=0.3)$. Therefore, 70 -min operation was selected as the standard time for simultaneous microalgae separation and cell disruption assays.

Azarian et al. (2007) evaluated electrolytic processes for microalgae removal from industrial effluents varying the power from 50 to $550 \mathrm{~W} . \mathrm{dm}^{-3}$. At powers higher than $200 \mathrm{~W} . \mathrm{dm}^{-3}$, turbidity removal exceeded $80 \%$ for 10 minutes of residence time. However, there is risk of metal leaching when using consumable electrodes of aluminum at high power.

Gao et al. (2010) evaluated microalgae harvesting by electrocoagulation-flotation, comparing the process efficiency using iron and aluminum electrodes, with a current density of $1 \mathrm{~mA} \mathrm{~cm}{ }^{-2}$, $\mathrm{pH}=4-7$, and algae density $=0.55 \times 10^{9}-1.55 \times 10^{9}$ cells $\mathrm{L}^{-1}$. These authors concluded that aluminum electrodes outperformed iron electrodes for algal removal and that electrolysis time required was shorter for aluminum electrodes. Abdala Neto \& Aquino (2012)

Table 4 - Spearman correlation coefficients ( $\rho$ ) related to microalgae incidence.

\begin{tabular}{|c|c|c|c|c|c|c|}
\hline Parameters & Aphanocapsa & Microcystis & Oscillatoria & Planktothrix & Chlorella & Euglena \\
\hline Alcalinity & 0.543 & -0.135 & 0.771 & 0.314 & 0.200 & -0.771 \\
\hline N & -0.486 & 0.270 & $-0.829^{*}$ & -0.029 & 0.086 & 0.314 \\
\hline Temperature & 0.600 & -0.270 & $0.943^{\star *}$ & 0.257 & 0.143 & -0.429 \\
\hline Total P & -0.257 & -0.541 & -0.371 & -0.257 & $-0.829^{*}$ & -0.257 \\
\hline $\mathrm{pH}$ & -0.638 & -0.394 & -0.232 & -0.580 & 0.725 & 0.522 \\
\hline$N: P$ & -0.200 & 0.439 & -0.429 & 0.200 & 0.486 & 0.257 \\
\hline
\end{tabular}

BOD: biochemical oxygen demand; P: phosphorus; DO: dissolved oxygen; *significant correlation at a level of 5\% (two-tailed); **significant correlation at a level of 1\% (one-tailed). 
compared a photoreactor (electro-oxidation and heterogenous photocatalysis) with pre-oxidants in a water treatment system. The photoreactor reached higher turbidity removal efficiency (99.5\%), higher COD removal (65.5\%) and higher chlorophyll a (98.97\%). It also removed higher concentrations of trihalomethanes (77.2 $\left.\mathrm{mg} \mathrm{L}^{-1}\right)$ in comparison to other pre-oxidants. Fen et al. (2007) evaluated several interferents in electrodes for humic acid removal the continuous usage of aluminum. Operating with current density of within 60 minutes, $97.8 \%$ of $4.76 \mathrm{~mA} \mathrm{~cm}^{-2}$ and $1-\mathrm{cm}$ space between the electrodes in acidic $\mathrm{pH}$, this process reached $97.8 \%$ humic acid removal within 60 minutes. Benhadji et al. (2011) evaluated an electro-coagulation process with aluminum electrodes treating tannery. By applying a current density of 7.5 $\mathrm{mA} \mathrm{cm}{ }^{-2}$ for 45 minutes, they achieved up to $90 \%$ of BOD, COD, turbidity, chrome, iron and nitrate removal.

In the scenario of the present study, with non-consumable electrodes constructed of stainless steel, high efficiencies could be reached with a power of only $20.7 \mathrm{~W} . \mathrm{dm}^{-3}$. Therefore, it was possible to achieve high microalgal removal efficiencies using lower power than reported in literature, with a method that can avoid metals release to the medium, which represents cost savings in the separation process and ensures the viability of biomass for energy purposes.

The lipid content of a mixed microalgae community from a waste stabilization pond rich in Chlorella was $21.4 \pm 2.02 \%$, which is close to reported values for pure cultures of representative species (LEE et al., 2010; PRABAKARAN \& RAVINDRAN, 2011; WAHLEN et al., 2011; DE GODOS et al., 2011). Wahlen et al. (2011) evaluated the lipid content of microalgae collected from a wastewater treatment plant using ultrasound sonication and lipid extraction using organic solvents and obtained a $14.4 \%$ lipid yield.
Several studies have been conducted to compare methods traditionally used as pretreatment for cell disruption of microalgae derived from either pure or mixed cultures. Koberg et al. (2011) compared the efficiency of microwaving ( $5 \mathrm{~min}$ at $70 \%$ power (cycle mode of $21 \mathrm{~s}$ on and $9 \mathrm{~s}$ off $)$ and ultrasound ( $20 \mathrm{kHz}, 40 \%$ amplitude for $5 \mathrm{~min})$ for disruption of microalgae of the genus Nannochloropsis with simultaneous extraction of lipids by the organic solvents. These authors achieved percentages (in biodiesel) of $10.7 \%$ in the control group, $18.9 \%$ in the group pretreated under ultrasound radiation and $32.8 \%$ in the group pretreated under microwave radiation. The authors related the results obtained to the higher temperature increase in microwave radiation process than the provided by sonication process, carrying the greatest cell disruption and the increased releasing of lipids for conversion to biodiesel by transesterification method.

Lee et al. (2010) compared five cell disruption methods: autoclave $\left(125^{\circ} \mathrm{C}\right.$ with $1.5 \mathrm{MPa}$ for $5 \mathrm{~min}$ ), bead-beating (2,800 rpm for $5 \mathrm{~min}$ ), microwave $\left(100^{\circ} \mathrm{C}\right.$ and $2,450 \mathrm{MHz}$ for $5 \mathrm{~min}$ ), ultrasound $(10 \mathrm{kHz}$ for $5 \mathrm{~min})$ and osmotic shock ( $10 \% \mathrm{NaCl}$ solution with a vortex for $1 \mathrm{~min}$ and maintained for $48 \mathrm{~h}$ ). The methods were applied to pure cultures of Botryococcus sp., Chlorella vulgaris and Scenedesmus sp. The efficiency of each method was measured by the achieved yield in the lipid extraction using chlorophorm and methanol. The authors obtained lipid percentages ranging from 5.4 to $11.9 \%$ using autoclaving, 10 to $28.6 \%$ using microwaving, and 6.1 to $8.8 \%$ using sonication.

Prabakaran \& Ravindran (2011) used ultrasound (50 Hz for $15 \mathrm{~min}$ ), microwave $\left(100^{\circ} \mathrm{C}\right.$ for $\left.5 \mathrm{~min}, 2,450 \mathrm{MHz}\right)$ and autoclave $\left(121^{\circ} \mathrm{C}\right.$ with $103.4 \mathrm{kPa}$ for $5 \mathrm{~min}$ ) methods for disruption of Chlorella cells and achieved lipid yields of $38 \%$ by microwaving, $24 \%$ by autoclaving and $40 \%$ by sonication. The utilization of single culture improve the efficiency of cell disruption and lipid extraction. However, mixed cultures
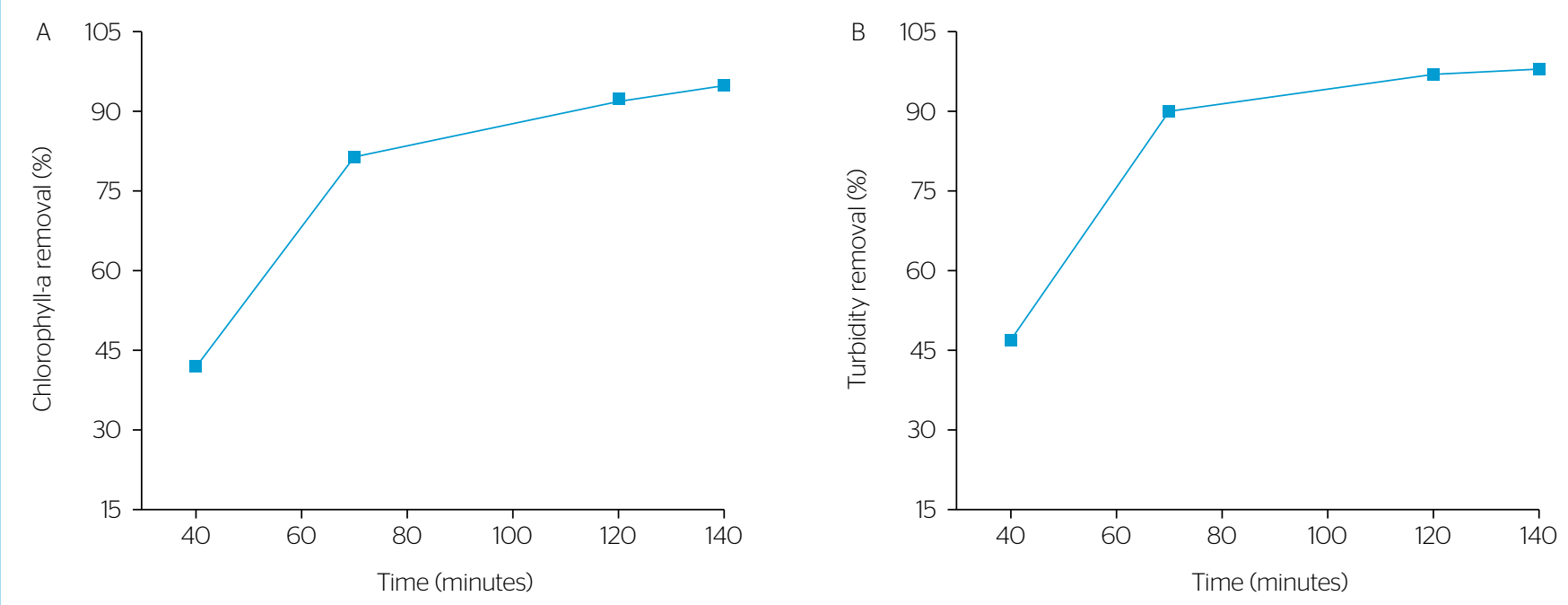

Figure 2 - (A) Chlorophyll and (B) turbidity removal (\%) by electroflotation by alternate current (EFAC). 
obtained from waste stabilization ponds, as the ones used on the present study, offer higher probability of application, while they remove the purification step from the process.

Wang et al. (2015) evaluated the cell disruption degree of a culture of Neochloris oleoabundans pretreated under ultrassonication (power of 400, 600 or $800 \mathrm{~W}$ for $50 \mathrm{~min}$ ), high-pressure homogenization (operating pressure of $40,50,60,70$ or $80 \mathrm{MPa}$ ), enzymatic hydrolysis (cellulase and / or papain) and the combination of enzymatic hydrolysis with high-pressure homogenization and ultrasonication (papain+cellulase, $600 \mathrm{~W}$ for 30 minutes, $80 \mathrm{Mpa}$ ). The highest disruption degree, up to $95.41 \%$, was achieved by the combination of enzymatic hydrolysis and high-pressure homogenization. The authors obtained $36 \%$ of lipid yield with the best method for cell disruption in comparison to the control group - with no pretreatment, which counted with $10 \%$ lipid yield.

Recently, Phong et al. (2018) investigated the effect of ultrasound (37 kHz for 1,200 s) on the cell disruption of Chlorella sorokiniana and Chlorella vulgaris for protein extraction. The authors observed that the sole application of ultrasonication for both strains provided two to three-fold increase in the protein yield compared to their corresponding control groups. Similar reults were obtained by Parimi et al. (2015), who found that ultrasonication (20\% maximum power for 60 $\mathrm{min}$ ) resulted in higher protein recovery $(69.9 \%)$ in the supernatant than that of the control group, without pretreatment step. The same authors performed autoclaving as pretreatment (at $121^{\circ} \mathrm{C}$ with 103.4 $\mathrm{kPa}$ for $30 \mathrm{~min}$ ), and high-pressure homogenization involving two passes through a high-pressure homogenizer (at 103.4 Mpa), obtaining 29 and 83.5\%, respectively. A study conducted by Araujo et al. (2013) observed that the application of ultrasonication $(40 \mathrm{kHz}$ with ultrasonic intensity of $29.7 \mathrm{~W} \mathrm{~L}^{-1}$ or $2.68 \mathrm{~W} \mathrm{~m}^{-2}$ ) in the extraction process was able to improve the extraction efficiency (52.5\%) of intracellular compounds in microalgae.

Regarding the application of EFAC reactor, this paper reported the first attempt of an efficient method for simultaneous microalgae separation and cell disruption. Thus, there is no data in literature that allow a comparative study, hampering an elaborated discussion.

\section{CONCLUSIONS}

The current paper described the first attempt at using an EFAC reactor for simultaneous microalgae separation and cell disruption, showing promising results for the application of EFAC to produce biodiesel from microalgae grown on waste stabilization ponds.

Phytoplankton genera predominant in the studied systems belonged to Chlorophyceae, Cyanophyceae and Euglenophyceae classes. These classes of microalgae normally present relatively high lipid content and predominantly saturated fatty acids, which can be advantageous in the production of biodiesel.

The lipid contents obtained with microalgae from stabilization ponds treating domestic wastewater resemble those yields obtained from microalgal biomass growth in conventional processes and reported in literature.

Regarding the application of EFAC reactor, as far as we are concerned, this is the first attempt of an experiment on simultaneous microalgae separation and cell disruption, with promising results for application in systems that produce this biomass for biodiesel production.

\section{ACKNOWLEDGEMENTS}

The authors would like to thank the Brazilian National Council for Scientific and Technological Development (Conselho Nacional de Desenvolvimento Científico e Tecnológico - CNPq), Coordination for the Improvement of Higher Education Personnel (Coordenação de Aperfeiçoamento de Pessoal de Nível Superior - CAPES), organizations of the Brazilian government for the development of science and technology for the scholarships, Studies and Projects Financing Agency (Financiadora de Estudos e Projetos - FINEP) for the financial support and Water and Wastewater Agency of Ceará (Companhia de Água e Esgoto do Ceará - CAGECE).

\section{REFERENCES}

ABDALA NETO, E.F;; AQUINO, M.D. (2012) Fotocatálise Heterogênea associada a eletrooxidação no pré-tratamento de água eutrofizada em uma estação piloto de tratamento de água. Revista AIDIS de Ingeniaría y Ciencias Ambientales: investigación, desarrollo y práctica, v. 5, n. 3, p. 11-19.

AMERICAN PUBLIC HEALTH ASSOCIATION (APHA); AMERICAN WATER WORKS ASSOCIATION (AWWA); WATER ENVIRONMENT FEDERATION (WEF). (2008) Standard Methods for the examination of Water and Wastewater. 21. ed. Washington, D.C.: American Public Health Association.

ARAUJO, G.S.; MATOS, L.J.; FERNANDES, J.O.; CARTAXO, S.J.; GONÇALVES, L.R.; FERNANDES, F.A.; FARIAS, W.R. (2013) Extraction of lipids from microalgae by ultrasound application: prospection of the optimal extraction method. Ultrasonics Sonochemistry, v. 20, n. 1, p. 95-98. https://doi.org/10.1016/j.ultsonch.2012.07.027 
ARAYA-FARIAS, M.; MONDOR, M.; LAMARCHE, F.; TAJCHAKAVIT, S.; MAKHLOUF, J. (2008) Clarification of apple juice by electroflotation, Innovative Food Science and Emerging Technologies, v. 9, n. 3, p. 320-327. http://dx.doi.org/10.1016/j.ffset.2007.08.002

AZARIAN, G.H.; MESDAGHINIA, A.R.; VAEZI, F; NABIZADEH, R.; NEMATOLLAHI, D. (2007) Algae removal by electro-coagulation process, application for treatment of the effluent from a industrial wastewater treatment plant. Iranian Journal of Public Health, v. 36, n. 4 , p. 57-64.

BAHR,M.;STAMS, A.J.;DELAROSA, F.; GARCIA-ENCINA, P.A.; MUÑOZ, R. (2O11) Assessing the influence of the carbon oxidation-reduction state on organic pollutant biodegradation in algal-bacterial photobioreactors. Applied Microbiology and Biotechnology, v. 90, n. 4, p. 1527-1536. http://dx.doi.org/10.1007/s00253-011-3204-8

BARROS, A.I.; GONÇALVES, A.L; SIMÕES, M.; PIRES, J.C.M. (2015) Harvesting techniques applied to microalgae: A review. Renewable and Sustainable Energy Reviews, v. 41, p. 1489-1500. http://dx.doi. org/10.1016/j.rser.2014.09.037

BELLINGER, E.G.; SIGEE, D.C. (2010) Freshwater algae - identification and use as bioindicators. Great Britain: Wiley-Blackwell.

BENHADJI, A.; AHMED, M.T; MAACHI, R. (2O11) Electrocoagulation and effect of cathode materials on the removal of pollutants from tannery wastewater of Rouïba, Desalination, v. 277, n. 1, p. 128-134. http://dx.doi.org/10.1016/j.desal.2011.04.014

BLIGH, E.G.; DYER, W.J. (1959) A rapid method of total lipid extraction and purification. Canadian Journal of Biochemistry and Physiology, v. 37, n. 8, p. 911-917. https://doi.org/10.1139/o59-099

BRENNAN, L; OWENDE, P. (2010) Biofuels from microalgae-A review of technologies for production, processing, and extractions of biofuels and co-products. Renewable and Sustainable Energy Reviews, v. 14, n. 2, p. 557-577. https://doi.org/10.1016/..rser.2009.10.009

CHAPLIN, B.P. (2014) Critical review of electrochemical advanced oxidation processes for water treatment applications. Environmental Science: Processes Impacts, v. 16, p. 1182-1203. https://doi.org/10.1039/C3EMO0679D

CHELLAPPA, N.T.; COSTA, M.A.M. (2003) Dominant and co-existing species of Cyanobacteria from a Eutrophicated reservoir of Rio Grande do Norte State, Brazil. Acta Oecologica, v. 24, suppl. 1, p. S3-S1O. http://dx.doi.org/10.1016/S1146-609X(03)00005-5

CHEN, B.; WAN, C.; MEHMOOD, M.A.; CHANG, J.; BAI, F.; ZHANG, X. (2017) Manipulating environmental stresses and stress tolerance of microalgae for enhanced production of lipids and valueadded products - A review. Bioresource Technology, v. 244, pt. 2 , p. 1198-1206. https://doi.org/10.1016/j.biortech.2017.05.170

CHISTI, Y. (2007) Biodiesel from microalgae. Biotechnology Advances, v. 25, n. 3. p. 294-306. https://doi.org/10.1016/j.biotechadv.2007.02.001

CUVIN-ARALAR, M.L.; FOCKEN, U.; BECKER, K.; ARALAR, E.V. (2004) Effects of low nitrogen-phosphorus ratios in the phytoplankton community in Laguna de Bay, a shallow eutrophic lake in the Philippines. Aquatic Ecology, v. 38, n. 3, p. 387-401. https://doi. org/10.1023/B:AECO.0000035174.35091.0b
DE GODOS, I.; GUZMAN, H.O.; SOTO, R.; GARCIAAENCINA, P.A.; BECARES, E.; MUÑOZ, R.; VARGAS, V.A. (2O11) Coagulation/ flocculation-based removal of algal-bacterial biomass from piggery wastewater treatment. Bioresource Technology, v. 102, n. 2, p. 923-927. https://doi.org/10.1016/j.biortech.2010.09.036

DE-BASHAN, L.E.; BASHAN, Y. (2010) Immobilized microalgae for removing pollutants: review of practical aspects. Bioresource Technology, v. 101, n. 6, p. 1611-1627. https://doi.org/10.1016/j. biortech.2009.09.043

DERNER, R.B.O.S.; OHSE, S.; VILLELA, M.; CARVALHO, S.M. FETT, R. (2006) Microalgas, produtos e aplicações. Ciência Rural, v. 36, n. 6, p. 1959-1967. http://dx.doi.org/10.1590/S010384782006000600050

DI BERNARDO, L. (1995) Algas e suas influências na qualidade das águas e nas tecnologias de tratamento. Rio de Janeiro: ABES.

ELAND, L.E.; DAVENPORT, R.J.; SANTOS, A.B.; MOTA FILHO, C.R. (2018) Molecular evaluation of microalgal communities in full-scale waste stabilisation ponds. Environmental Technology, v. 2, p. 1-8 https://doi.org/10.1080/09593330.2018.1435730

FEN, Q.Y.; LI, X.-D.; CHENG, I.J.; MENG, L.; MENG, Q.J. (2007) Removal of Humic Acid from Groundwater by Electrocoagulation, Journal of China University of Mining \& Technology, v. 17, n. 4, p. 513-515 https://doi.org/10.1016/S1006-1266(07)60136-9

GAO, S.; YANG, J.; TIAN, J.; MA, F.; TU, G.; DU, M. (2010) Electrocoagulation-flotation process for algae removal. Journal of Hazardous Materia/s, v. 177, n. 1-3, p. 336-343. https://doi.org/10.1016/j. jhazmat.2009.12.037

GHOSH, S.; LOVE, N. G. (2O11) Application of rbcL based molecular diversity analysis to algae in wastewater treatment plants. Bioresource Technology, v. 102, n. 3, p. 3619-3622. https://doi. org/10.1016/j.biortech.2010.10.125

GRIMA, E.M.; BELARBI, E.H.; ACIÉN FERNÁNDEZ, F.G.; ROBLES MEDINA, A., CHISTI, Y. (2003) Recovery of microalgal biomass and metabolites: process options and economics. Biotechnology Advances, v. 20, n. 7-8, p. 491-515. https://doi.org/10.1016/S07349750(O2)00050-2

HUYNH, M.; SEREDIAK, N. (2006) Algae Identification: field guide. Canada: Agriculture and Agri-Food Canada. p. 40.

KOBERG, M.; COHEN, M.; BEN-AMOTZ, A.; GEDANKEN, A. (2O11) Bio-diesel production directly from the microalgae biomass of Nannochloropsis by microwave and ultrasound radiation. Bioresource Technology, v. 102, n. 5, p. 4265-4269. https://doi. org/10.1016/..biortech.2010.12.004

LEE, J.Y; YOO, C; JUN, S.Y.; AHN, C.Y; OH, H.M. (2O10) Comparison of several methods for effective lipid extraction from microalgae. Bioresource Technology, v. 101, n. 1, suppl., p. S75-S77. https://doi. org/10.1016/j.biortech.2009.03.058

LOVINS, L.H. (2008) Rethinking production. In: WORLDWATCH INSTITUTE (Ed.). Worldwatch Institute report State of the World 2008: Innovations for a Sustainable Economy. Washington, D.C.: Worldwatch Institute. v. 34 
MARA, D.; HORAN, N. (2003) The handbook of water and wastewater microbiology. 6. ed. London: Academic Press.

MATA, T.M.; MARTINS, A.A.; CAETANO, N.S. (2010) Microalgae for biodiesel production and other applications: A review. Renewable and Sustainable Energy Reviews, v. 14, n. 1, p. 217-232. https://doi. org/10.1016/j.rser.2009.07.020

MULBRY, W.; KONDRAD, S.; PIZARRO, C.; KEBEDE-WESTHEAD, E. (2008) Treatment of dairy manure effluent using freshwater algae: algal productivity and recovery of manure nutrients using pilotscale algal turf scrubbers. Bioresource Technology, v. 99, n. 17, p. 8137-8142. https://doi.org/10.1016/j.biortech.2008.03.073

MUÑOZ, R., GUIEYSSE, B. (2006) Algal-bacterial processes for the treatment of hazardous contaminants: a review. Water Research, v. 40, n. 15, p. 2799-2815. https://doi.org/10.1016/j.watres.2006.06.011

PADISÁK, J.; BORICS, G.; FEHÉR, G.; GRIGORSZKY, I.; OLDAL, I.; SCHMIDT, A.; ZÁMBÓNÉ-DOMA, Z. (2003) Dominant species, functional assemblages and frequency of equilibrium phases in late summer phytoplankton assemblages in Hungarian small shallow lakes. Hydrobiology, v. 502, n. 1-3, p. 157-168.

PALMER, C.M. (1969) A composite rating of algae tolerating organic pollution. Journal of Phycology, v. 5, n. 1, p. 78-82. https://doi. org/10.1111/j.1529-8817.1969.tbO2581.x

PARIMI, N.S.; SINGH, M.; KASTNER, J.R.; DAS, K.C.; FORSBERG, L.S.; AZADI, P. (2015) Optimization of protein extraction from Spirulina platensis to generate a potential co-product and a biofuel feedstock with reduced nitrogen. Frontiers in Energy Research, v. 3, p. 1-9. https://doi.org/10.3389/fenrg.2015.00030

PARSA, J.B.; REZAEI, M.; SOLEYMANI, A.R. (2009) Electrochemical oxidation of an azo dye in aqueous media investigation of operational parameters and kinetics. Journal of Hazardous Materials, v. 168, n. 2-3, p. 997-1003. http://dx.doi.org/10.1016/j. jhazmat.2009.02.134

PASTICH, E.A.; GAVAZZA, S.; CASÉ, M.C.C.; FLORENCIO, L.; KATO, M.T. (2016) Structure and dynamics of the phytoplankton community within a maturation pond in a semiarid region. Brazilian Journal of Biology, v. 76, n. 1, p. 144-153. http://dx.doi.org/10.1590/1519-6984.15214

PATIL, H.S.; DODAKUNDI, G.B.; RODGI, S.S. (1975) Succession in Zoo- and phytoplankton in a domestic wastewater stabilization pond. Hydrobiology, v. 47, n. 2, p. 253-264. https://doi.org/10.1007/ BF00039058

PEARSON, H. (2008) Microbiology of waste stabilization ponds. In: IWA (Ed.). Integrated Environmental Technology. London: IWA. 479 p.

PHAM, D.T.; EVERAERT, G.; JANSSENS, N.; ALVARADO, A.; NOPENS, I.; GOETHALS, P.L.M. (2014) Algal community analysis in a waste stabilisation pond. Ecological Engineering, v. 73, p. 302-306. http:// dx.doi.org/10.1016/j.ecoleng.2014.09.046

PHONG, W.N.; SHOW, P.L.; LE, C.F.; TAO, Y.; CHANG, J-S.; LING, T.C. (2018) Improving cell disruption efficiency to facilitate protein release from microalgae using chemical and mechanical integrated method, Biochemical Engineering Journal, v. 135, p. 83-90. https:// doi.org/10.1016/j.bej.2018.04.002

PRABAKARAN, P.; RAVINDRAN, A.D. (2011) A comparative study on effective cell disruption methods for lipid extraction from microalgae. Letters in Applied Microbiology, v. 53, n. 2, p. 150-154 https://doi.org/10.1111/j.1472-765X.2011.03082.x

PUYOL, D.; BATSTONE, D.J.; HÜLSEN, T.; ASTALS, S.; PECES, M.; KRÖMER, J. O. (2017) Resource Recovery from Wastewater by Biological Technologies: Opportunities, Challenges, and Prospects. Frontiers in Microbiology, v. 7, p. 2106. https://dx.doi. org/10.3389\%2Ffmicb.2016.02106

RASLAVIČIUS, L.; STRIŪGAS, N.; FELNERIS, M. (2018) New insights into algae factories of the future. Renewable and Sustainable Energy Reviews, v. 81, n. 1, p. 643-654. https://doi.org/10.1016/j.rser.2017.08.024

RAWAT, I.; RANJITH KUMAR, R.; MUTANDA, T.; BUX, F. (2011) Dual role of microalgae: Phycoremediation of sewage and biomass production for sustainable biofuels production. Applied Energy, v. 88, n. 10, p. 3411-3424. http://dx.doi.org/10.1016/j.apenergy.2010.11.025

RAZZAK, S.A.; ALI, S.A.M.; HOSSAIN, M.M.; DELASA, H. (2O17) Biological $\mathrm{CO}_{2}$ fixation with production of microalgae in wastewater - A review. Renewable and Sustainable Energy Reviews, v. 76, p. 379-390. http://dx.doi.org/10.1016/j.rser.2017.02.038

SARKAR, M.S.K.A.; DONNE, S.W.; EVANS, G.M. (2011) Utilization of hydrogen in electroflotation of sílica, Advanced Powder Technology, v. 22, n. 4, p. 482-492. http://dx.doi.org/10.1016/j.apt.2011.05.007

SHUBA, E.S.; KIFLE, D. (2018) Microalgae to biofuels: 'Promising' alternative and renewable energy, review. Renewable and Sustainable Energy Reviews, v. 81, n. 1, p. 743-755. http://dx.doi. org/10.1016/j.rser.2017.08.042

SILVA, A.P.F.S.; COSTA, M.C.; LOPES, A.C.; ABDALA NETO, E.F.; LEITÃO, R.C.; MOTA, C.R.; SANTOS, A.B. (2014) Comparison of pretreatment methods for total lipids extraction from mixed microalgae. Renewable Energy, v. 63, p. 762-766. http://dx.doi.org/10.1016/j.renene.2013.10.038

SIRÉS, I.; BRILLAS, E.; OTURAN, M.A.; RODRIGO, M.A.; PANIZZA, M. (2014) Electrochemical advanced oxidation processes: today and tomorrow. A review. Environmental Science Pollution Research, v. 21, n. 14, p. 8336-8367. https://doi.org/10.1007/s11356-014-2783-1

VAN LOOSDRECHT, M.C.M.; BRDJANOVIC, D. (2014) Anticipating the next century of wastewater treatment. Science, v. 344, n. 6191, p. 1452-1453. https://doi.org/10.1126/science.1255183

WAHLEN, B.D.; WILLIS, R.M.; SEEFELDT, L.C. (2011) Biodiesel production by simultaneous extraction and conversion of total lipids from microalgae, cyanobacteria, and wild mixed-cultures. Bioresource Technology, v. 102, n. 3, p. 2724-2730. https://doi. org/10.1016/j.biortech.2010.11.026

WANG, D.; LI, Y.; HU, X.; SU, W.; ZHONG, M. (2015) Combined enzymatic and mechanical cell disruption and lipid extraction of green alga Neochloris oleoabundans. International Journal of Mollecular Science, v. 16, n. 4, p. 7707-7722. https://doi.org/10.3390/ijms16047707 